The Review of Finance and Banking

Volum e 05, Issue 1, Year 2013, Pages 007-026

S print ISSN 2067-2713, online ISSN 2067-3825

\title{
INVESTMENT CASH FLOW SENSITIVITY AND MANAGERIAL OPTIMISM: A LITERATURE REVIEW VIA THE CLASSIFICATION SCHEME TECHNIQUE
}

\author{
EZZEDDINE BEN MOHAMED, BACCAR AMEL, AND ABDELFATTEH BOURI
}

\begin{abstract}
In this paper, we present a literature review and classification scheme for investment cash flow sensitivity under behavioral corporate finance (hereafter, $\mathrm{BCF}$ ). The former consists of all published articles between 2000 and 2011 in different journals that are appropriate outlets for BCF research. The articles are classified and results of these are presented and analyzed. The classification of articles was based on nine criteria; journals, date of publication, paper nature, the context of the study adopted behavioral biases, adopted approach, behavioral biases measurement, the adopted assumption, econometric approach and empirical findings. Literature on investment cash flow sensitivity under behavioral corporate finance isn't well developed. In fact, the behavioral corporate finance is very young. Our review shows that behavioral biases (optimism and overconfidence) have an explanatory power and they can succeed to explain the dependence of corporate investment on the internal cash flow availability. This result is protected in the most cases by the some restrictive assumptions: the absence of agency costs and asymmetric information. Based on the review, suggestions for future research are likewise provided.
\end{abstract}

\section{INTRODUCTION}

The corporate investment decision has been widely studied in financial literature. Several empirical studies are conducted on the subject. An excellent survey is offered by Harris and Raviv (1991), Shleifer and Vishny (1997) and Hubbard (1998). In financial literature, two main hypotheses are proposed to explain the corporate investment distortions. The first is spawned by Jensen and Meckling (1976) in agency framework. Managers are supposed to be opportunistic and seek to maximize their own utility function. They insist on the existence of conflicts of interest between management and shareholders. Managers will overinvest to increase their executives and escape the control exercised over them. The second explanation is derived from information asymmetry between corporate insiders and the capital market, Myers and Majluf (1984). Information asymmetry creates an undervaluation of good firms. This can cause problems of financing and results in a state of under-investment.

With agency problems and asymmetric information, the investment decision depends on capital structure. These two theories insist on the presence of investment cash-flow sensitivity phenomena. The agency theory postulates that managers will increase firms' investment level with the availability of internal cash flow in order to escape from the market control in case

Received by the editors May 7, 2012. Accepted by the editors April 21, 2013.

Keywords: Behavioral corporate finance; literature review; classification scheme technique; investment cash flow sensitivity; optimism and overconfidence.

JEL Classification: G02; G30; G31; G32.

Ezzeddine Ben Mohamed is a Ph. D. in Accounting and Financial Methods at the Unit of Research Corporate Finance and Financial Theory (COFFIT), FSEG Sfax. Tunisia. Email: benmohamed.ezzeddine@yahoo.fr.

Baccar Amel is a Ph. D. in Accounting and Financial Methods at the Unit of Research Corporate Finance and Financial Theory (COFFIT), FSEG Sfax, Tunisia. Email: amel.baccar2@gmail.com.

Abdelfatteh Bouri is Professor of Finance at the Unit of Research Corporate Finance and Financial Theory (COFFIT), FSEG Sfax, Tunisia. Email: Abdelfettah.Bouri@fsegs.rnu.tn.

This paper is in final form and no version of it will be submitted for publication elsewhere. 
of external funding. In the presence of sufficient internal cash flow, investment increases and the probability of investment distortion increases. With asymmetric information theory, there will be sensitivity between corporate investment and internal cash flow. Managers will restrict external finance in order to avoid current share dilution; as a result investment will strongly depend on internal finance.

In other interesting way to study the corporate investment and liquidity relationship was advanced by a seminal paper by Fazzari et al., (1988). Beyond traditional explanation of the investment cash flow sensitivity, that are based on the agency conflicts between shareholders and management and the effect of the asymmetric information problem that make firm's investment dependent to internal funds availability and level, the firms' financial constraints degree can largely derive the investment-liquidity equation. They use some criteria to classify firms in their sample according to their financial constraint degrees.

Empirically, field studies validate the existence of cash-flow sensitivity phenomenon (Fazzari, Hubbard and Peterson (1988), Kaplan and Zingales (1997, 2000)). These researches link the sensitivity to capital market imperfections and financing constraints. The majority of studies in this field conclude to the existence of a positive correlation between corporate investment and it cash flow. According to Fazzari et al (1988) the investment cash flow sensitivity is stronger for the more constrained firms among less constrained one. They argument that, if firm runs financial constraints, it will have big difficulties to obtain external financing. Then it will be attached to its internal funds. This make its investment policy very closed to the cash flow availability. However, Kaplan and Zingales (1997) depart from the Fazzari et al., (1988) sample and find opposite results.

They find that less constrained firms are those who apply the strongest investment cash flow sensitivity. This is a real challenge! Allayannis and Mozumdar (2004) argue that the inclusion of negative cash flow can influence this sensitivity relationship. Many other explanations are advanced in order to resolve the debate. Another way to explain such empirical finding is that more constrained firms have a very low cash flow level and so the investment-liquidity relationship may be poor or insignificant.

The previous cited factors; agency costs, asymmetric information and financial constraints may cause investment cash flow sensitivity. They may cause an inefficiency of corporate investment policy. This will be observable in a form of either overinvestment or underinvestment. For this reason, some papers tend to study the investment cash flow sensitivity in a corporate governance framework. These studies aim to detect the effect of corporate governance mechanisms on the investment cash flow sensitivity. These studies can be exploited in order to determinate the optimal structure of corporate governance mechanisms that can succeed to overcome the agency and asymmetric information problems and so reduce these impacts on firm's investment policy (see for example studies by Kahuria and Muller (1995), Hadlock (1998), Gugler and Yurtoglu (2003), Gugler (2003), Haid and Weigand (2001), Degryse and de Jong (2000), Piandado and de la Torre (2004), Goergen and Renneboog (2001) and Pawlina and Renneboog (2005).

A feature keys in these explanations that they derive from the standard corporate finance literature which assumed that investors and managers are rational enough to maximize their utilities functions. They are also assumed to make a rational decision based on a methodological development and selection criteria. This means that investment distortions are only results of capital markets imperfections, asymmetric information or agency conflicts.

The cognitive and experimental psychology literature documents that individual are normal and are far from the "super-calculator" (Statman, 2005). They are affected by their cognitive and psychological biases such as mental accounting, optimism and overconfidence. Lopes (1987) develops the security potential and aspiration level (SPA) to describe individuals' behaviours which are governed by the hope and fear emotions. When choosing and constructing their portfolio they act according their emotions (Shefrin and Statman, 2000). Many other papers critics the full rational agent assumption and show that agent behave an irrational manner. They may opt for a herding behaviour, over and under reactions among other behaviours. 
In contrast to the traditional economists who always based their analysis of financial markets and corporate finance on some restrictive assumptions such as the full rational agents, emotionless, self-interested maximizers of expected utility, behavioral finance largely critics these assumptions. Beyond the agency theory, the contribution of asymmetric information theory, the capital market imperfections and the financial constraints, the behavioral corporate finance $(\mathrm{BCF})$ is an attractive way to find explanations to investment cash flow sensitivity other than related to the firm' characteristics. This approach studies the effect of behavioral biases on corporate decision. ${ }^{1}$

In sum, the literature review on the field of investment cash flow sensitivity proposes three explanations to this phenomenon (see figure 1). From standard finance point of view, agency problems and asymmetric information can lead to investment cash flow sensitivity. In other hand, the behavioral corporate finance proposes other possible sources deriving mainly from the cognitive psychology literature, where behavioral biases should have an explanatory power on the relationship between firms' cash flow and corporate investment.

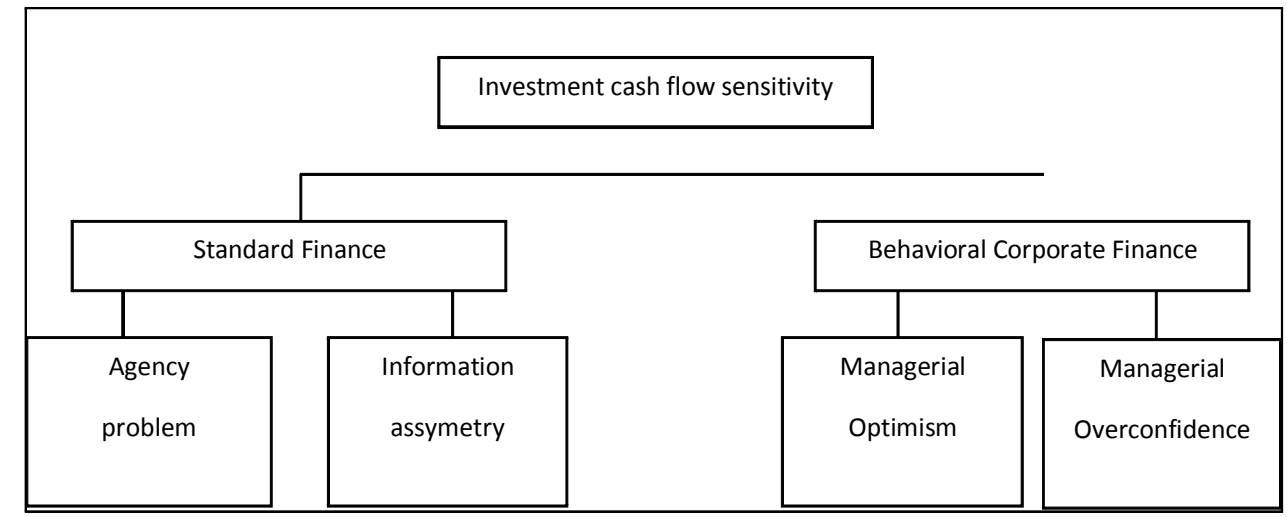

Figure 1: Investment cash flow sensitivity between standard and behavioral finance

These potential explanations mainly analyze the investment-cash flow sensitivity under the financial constraint hypothesis. Agency conflicts, asymmetric information problems and managerial optimism can explain the corporate investment distortions but their potential effects should studied also by introducing if the firm is financially constrained or not. We should note also that there are some other explanations such as the corporate governance mechanisms.

The behavioral corporate finance is very young (Fairchild, 2007) and it essays to generate theoretical and empirical contributions to explain investment-cash flow sensitivity under personal characteristics of firms' managers. While there are many survey papers that discuss the investment cash flow sensitivity under standard finance theories, in our knowledge, there is no survey paper that focuses on the investment-cash flow sensitivity under behavioral corporate finance.

In this paper, we present an original literature review based on classification scheme technique. We essay to offer a review of the major literature and key findings on investment cash flow sensitivity under behavioral corporate finance. An extensive literature search of academic journals from 2002 to 2011 was conducted, yielding a total of 6 articles. The details of the literature search procedure are largely discussed in what follow and the limited number of published paper in this area of research will be justified.

\footnotetext{
${ }^{1} 1$. We can find an excellent literature review of many different types of behavioral biases that financial decision makers might hold and how these biases might affect decision making by referring to Barberis and Thaler (2000).
} 
Our objective is that this paper will serves as a roadmap in this field and help simulate further interest. Even if the literature review isn't large in investment cash flow sensitivity under managerial optimism, the methodology adopted by this survey paper will offer very interesting concluding remarks and suggest future directions of research in this subject.

The rest of paper is organized as follows: Section two backgrounds central concept of our research: behavioral corporate finance and investment cash flow sensitivity. Section three introduces the applied methodology for this study, while section four presents our results. Section five offers a discussion of new area of research regarding the corporate investment efficiency and growth opportunity efficiency. Finally, section six ends the paper by offering conclusions and attempts to provide some perspectives on future research and presents the classification scheme of investment cash flow sensitivity under behavioral corporate finance.

\section{Defining Behavioral Corporate Finance (BCF) and investment cash flow SENSITIVITY}

Traditional finance literature rises up on some restrictive hypothesis, mainly, the efficient market hypothesis (EMH) and the agents' rationality one. Two hypotheses largely affect the economic and financial models. However, in real word, markets have not been efficient in a strict sense and the inefficiency literature capitalizes on the existence of a series of phenomena that contradict the EMH. To save space, we only cited some of them, such as the January effect, momentum, and over-reaction and under-reaction.

The second pillar hypothesis in traditional finance literature is the assumption of "full rational agents". In terms of corporate finance, managers are supposed to be rational, emotionless and their decisions are not affected by their psychological biases. This assumption was the aim of many critics. For example, Kahneman and Tversky (1979) demonstrate that individuals has an S-shaped utility function reflecting that they are risk-averse in the domain of gains while they are risk-seeking in the domain of losses. Weinstein (1980) reports that individuals have a rosy view and that they are optimistic. Lopes (1987) developed the SPA theory where individuals are governed by their emotions, namely hope and fear emotions. Overconfidence and optimism has also a large foundation in financial literature and its effects are well documented and surveyed.

Corporate finance literature strives to evolve and adapt to these new experimental observable behaviours that are against the rationality assumption. Baker et al., (2012) conclude that the new approach, behavioral corporate finance replaces the traditional rationality assumptions with potentially more realistic behavioral assumptions. In fact, this approach has its own assumptions.

Behavioral corporate finance allows cognitive psychology to play a potentially important role in finance (Kim et al. 2008). In this new framework, people are assumed to be not fully rational so their financial decision may be driven by their behavioral biases and emotions. It studies the effect of behavioral biases on corporate decisions. We can find an excellent literature review of many different types of behavioral biases that financial decision makers might hold and how these biases might affect decision making by referring to Barberis and Thaler (2000). Behavioral corporate finance is a recent bloc of behavioral finance literature. We insist on the existence of two approaches: the irrational investors approach and the irrational managers approach.

Since the aim of this survey paper is to offer a literature review on a special corporate finance area which is the investment cash flow sensitivity, we discuss in what follows in some depth this concept and we offer also a short discussion concerning the determinants of the sensitivity between corporate investment and internal funds. This will help us to concern these determinants and also to show the contribution of the behavioral corporate finance in resolving the important question in corporate finance framework: what derives the investment cash flow sensitivity? 
Investment cash flow sensitivity literature recognizes that beyond the perfect world of Modigliani and Miller (1953), investment decision depends on financing funds availability. Empirical studies by Fazzari et al., (1988), Kaplan and Zingales (1997) among others document that firms investment policies are sensitive to internal funds availability. It means that firms' investment level is proportional to its available internal source of financing. This will cause distortions in their investment policies. Investment cash flow sensitivity is associated with both underinvestments when cash flows are low and overinvestment when cash flows are high.

While the standard corporate finance proposes explanations to the investment-liquidity sensitivity in the basis of agency costs and conflicts as is initiated by Jensen and Meckling (1976) and the asymmetric information problems (Myers and Majluf, 1984). The behavioral corporate finance itself proposes a new explanation of this phenomenon. Personal characteristics of Chief Executive Officer should have an explanatory power.

In a seminal paper, Heaton (2002) initiates a debate concerning the potential effect of CEOs' optimism bias on corporate investment policy. He defines optimistic managers when they systematically overestimate the probability of good firm performance and underestimate the probability of bad firm performance. Departing from a simple corporate finance model, he theoretically predicts that if managers are frapped by their optimism bias, they may cause underinvestment or overinvestment. Managerial optimism can so explain firms' investment distortions. Managerial optimism is assumed to have the same definition and impact on corporate investment sensitivity to cash flow. Optimistic managers will always perceive that stock market under value their firms. Optimistic CEOs will think that their investment projects are better than their true value. In term of financial strategy, they perceive that external financing will be costlier than the internal one. For this reason, they should be attached to their internal financing source. Therefore, investment will depend on internal cash flow availability and level.

\section{Methodology}

$\mathrm{Li}$ and Gavusgil (1995) stated that the investigation of the state of knowledge in a field or subject can be studied using three basic approaches. The first one is the Delphi technique through which experts who are familiar with the area are surveyed. The meta-analysis is the second approach. With such a method, empirical studies on the specific subject are gathered and statistically analyzed. Finally, the third approach is the content analysis. This last approach is applied in this paper.

The content analysis is a research method for systematic, qualitative and quantitative description of the manifest content of literature in a special area (Marasco, 2008). Following Li and Gavusgil (1995) and Seuring et al., (2005), to conduct an investigation by the content analysis, we should concentrate on two major steps: in the first step, it is primordial to define the sources and procedures for the search of articles to be analyzed. In a second step, we should define categories instrumental to the classification of the collected articles.

3.1. Literature search procedure. This survey was based on a study of journals, hence, we exclude conference proceeding papers, master's thesis, doctoral dissertations, textbooks, and unpublished working papers. According to Nord et al. (1995), academics and practitioners usually use journals most often for acquiring information and disseminating new findings and represent the highest level of research. We notice that articles are all related to investment cash flow sensitivity under behavioral corporate finance.

We use some selection criteria to select and accept articles in this study. If papers did not met the selection criteria, then they should be excluded. The research procedure takes two steps: (1) at the first step, articles were found via electronic search of the topic areas. We use different terms when searching for paper to be considered, namely, we use the terms (i) investment cash flow sensitivity, (ii) behavioral corporate finance, (iii) managerial overconfidence and, (iv) managerial optimism. 
The first term is used in order to generate all articles that treat investment cash flow sensitivity including papers that refer to this phenomenon via the standard finance. The second terms aims to find all articles related to behavioral corporate finance. This is an attempt to delimit papers that are related to investment cash flow sensitivity under behavioral corporate finance. Finally, the terms managerial overconfidence and managerial optimism may help us to find some papers that treats investment cash flow sensitivity under managerial overconfidence or optimism. These two terms are used since the overconfidence and optimism biases are the most known and studied in a behavioral corporate finance framework.

As mentioned before, papers that are included in this literature review are limited to published works obtained from electronic sources. Our search covers literature obtained from different electronic sources, precisely, we explore Science Direct, Springer Link, JSTOR, Wiley Interscience, Inderscience databases and Ingenta Connect databases. To obtain additional sources of information, we examine references cited in each relevant literature.

The research papers cover a period of ten years between 2002 and 2011. The choice of the starting date is governed by the publication of the first theoretical work spawned by Heaton (2002) published in the Financial Management journal.

In a second step, we exclude all papers that are not related to investment cash flow sensitivity under a behavioral framework. This means that we analyze each paper and on the basis of the title of manuscripts, its abstract and keys words, we decide to exclude or conserve it. Finally, papers are fully analyzed and we include only papers that are at the heart of the field analyzed here. After running the research papers procedure, we obtain only 6 papers that respond to all selection criteria.

Although the limited number of papers that we found, the classification scheme still an attractive technique since it can classify the considered literature and offer details in the tendency of the studies in investment cash flow sensitivity under behavioral corporate finance. This will be an easy task after proposing a classification method.

\subsection{Classification method.}

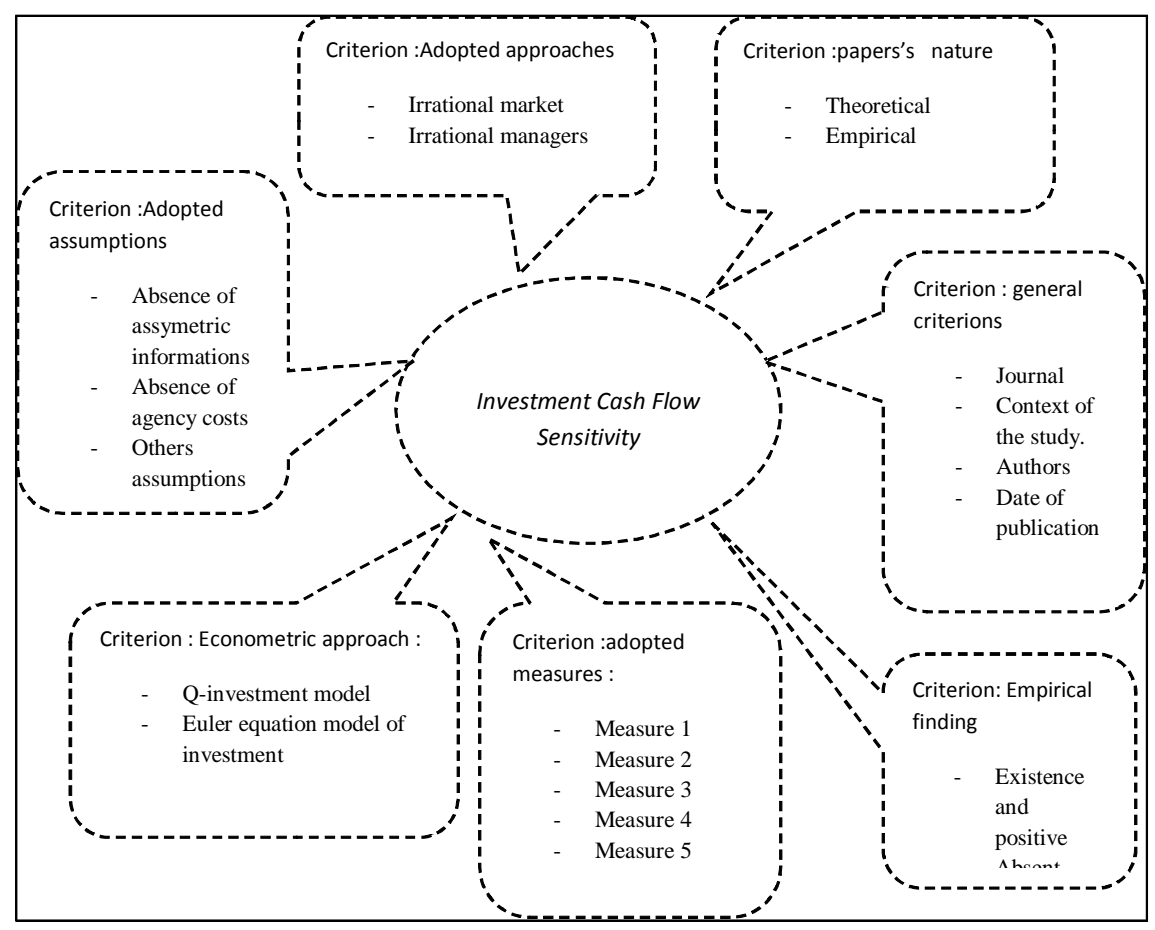

Figure 2: The proposed classification scheme 
The classification framework, as it presented in Figure 2, is based on the literature review and some research in the field of behavioral corporate finance (Baker et al., 2004). The articles were classified into seven broad categories: (i) The adopted approach (ii) the nature of the paper, (iii) general criterions such as the context of the study, journals, authors and the date of publication (iv) The optimism or overconfidence measurement (v) the econometric approach (vi) adopted assumptions and (vii) empirical finding. We note that each category is divided into subcategories. We will discuss all of them in what follows.

3.2.1. The nature of papers. According to this criterion, papers will be classified into two categories: a theoretical paper or an empirical one. We mean here by theoretical paper all paper that treats the problematic of investment cash flow sensitivity via the behavioral corporate finance without an empirical analysis.

3.2.2. Approaches. Literature in this classification is mainly divided into two broad categories: irrational manager approach or irrational market approach.

The irrational managers approach. The irrational managers approach assumes that managers are irrational and they operate in efficient capital market. To be more precise, by irrational managerial behaviour we mean behaviour that departs from rational expectations and expected utility maximization of the manager. According to Baker et al., (2004), this approach studies how irrational managers behave in the presence of rational investors.

The irrational markets approach. According to Baker et al., (2012), the "irrational investors approach" assumes that securities market arbitrage is imperfect, and thus that prices can be too high or too low. Simply, we can affirm that it is an approach that studies how rational managers behave in the presence of irrational investors.

3.2.3. Behavioral biases. Behavioral corporate finance (BCF) studies the effect of behavioral biases on corporate decision. We can find an excellent literature review of many different types of behavioral biases that financial decision makers might hold and how these biases might affect decision making by referring to Barberis and Thaler (2000). In this paper, we focus on behavioral biases that seem most used in this field: overconfidence and optimism. We mention in what follows a brief definition for each subcategory.

Overconfidence. The overconfidence effect is a well-established bias in which someone's subjective confidence in their judgments is reliably greater than their objective accuracy, especially when confidence is relatively high, (Gerry et al., 2002).

Optimism. Weinstein (1980) talks about the rosy vision that characterizes most of the people. It emphasizes the existence of the so-called unrealistic optimism. He shows that over $90 \%$ of those surveyed think that they are above average in such domains as driving skill, ability to get along with people and the sense of humour. Other studies such as that conducted by Buehler, Griffin and Ross (1994) show that people are optimistic. Optimism bias may be active in managers or among investors. So, we can speak of managerial optimism or optimistic markets. The first type of optimism rises up when a research adopts the irrational manager approach while the second type exists when the irrational investors approach is adopted. Even if these two biases were used to mean the same thing, we base our classification on the linguistic term "optimism" and "overconfidence".

3.2.4. Behavioral biases measures. By adopting this criterion, articles will be classified on the basis of behavioral biases measures. To our best of knowledge, there is no previous work that reviews papers in this research area and discusses these measures. Measures will be identified, discussed and then literature review will be classified on their basis.

We can find also a simple categorization of optimism and overconfidence measures and a short comparison of them. This will probably help advancing research in this field by making easy the assimilation of all existent measures and their drawbacks and benefits. 
3.2.5. Adopted assumptions. According to this criterion, articles will be classified into the adopted assumption. We focus, especially, on the presence or absence of assumptions relative to agency problems, information asymmetry or financial constraint when investigating the relationship between corporate investment and cash flows under managerial optimism or overconfidence.

3.2.6. The econometric approach. In financial literature, the most popular approaches to test investment cash flow sensitivity suppose the examination of two investment models: the Qmodel of investment and the Euler equation model. According to Perotti and Gelfer, 2001; Goergen and Renneboog, 2001, Allayannis and Mozumdar, 2004; Shen and Wang, 2005 and Aggrawal and Zong, 2006, each model has its own positive and negative points. The Q model affirms that firms investments are mainly determined by expectations of future profit opportunities calculated by the ratio of the market value of assets to its replacement value. An adjusted Q-model of investment was developed by Agca and Mozumdar, 2008 to include the availability of internal funds as an additional determinant of corporate investment.

The Euler equation model postulates that firms current investments are determined by its total sales, cash flows, past investments and total debt ${ }^{2}$ (Laeven, 2003).

3.2.7. Empirical findings. According to this criterion, papers will be classified using the sign of the coefficient between corporate investment and internal cash flows multiplied by a proxy of managerial optimism or overconfidence. We will focus on the validation of the theoretical prediction of the behavioral corporate finance that insists on the existence of a positive sign for this coefficient.

\section{Results}

4.1. The distribution of articles by journal. The number of papers that focus on investment cash flow sensitivity under behavioral corporate finance seems to be very limited. Table 1 shows the distribution of articles in different journals.

Table I: The distribution of papers by journals between 2000 and 2011

\begin{tabular}{|l|l|l|l|}
\hline Journals & $2000-2005$ & $2005-2011$ & Total \\
\hline The Journal of Financial Economic & - & 1 & 1 \\
\hline The Journal of Finance & 1 & - & 1 \\
\hline European Financial Management & 1 & - & 1 \\
\hline Pacific-Basin Finance Journal & 1 & 1 & 2 \\
\hline Financial Management & 1 & - & 1 \\
\hline Total & 4 & 2 & 6 \\
\hline
\end{tabular}

The Pacific-Basin Finance Journal published about 40 percent of the total of articles. This percentage is partially the result of the publication of a special issue on behavioral finance in Asia. The journal focuses on investment cash flow sensitivity are very reputable since the sample includes the Journal of Finance and the Journal of Financial Management. Another remarkable thing is that 4 papers were published after 2002. It is the date of the publication of the first paper that theoretically opens the door for the study of the effect of managerial optimism on corporate decision making including investment cash flow sensitivity.

It is clear that research in this field of finance is concentrated on three dates 2002, 2005 and 2011. This distribution may be explained by the difficulties when constructing robust measures of behavioral biases. In 2005, Malmendier and Tate propose possible measure of managerial overconfidence in two works (2005a and 2005b). Lin et al. also propose another alternative measure of optimism in the same year. This will be a solid factor that can explain the growth of the number of articles focusing on investment cash flow sensitivity.

\footnotetext{
${ }^{2}$ 2. See Bond and Meghir (1994) for the derivation of the Euler equation model and Hubbard (1998) to see the detail of derivation of the Q-model of investment.
} 
4.2. The classification of papers by authors, context of studies and date of publications. Table 2 simply classifies papers in our sample by authors, the nature of papers, the context of the study and the date of publications.

Table II: Distribution of papers by journals between 2000 and 2011

\begin{tabular}{|l|l|l|l|}
\hline Authors & Date of Publication & Nature of paper & Context \\
\hline Heaton & 2002 & Theoretical paper & - \\
\hline Malmendier and Tate & $2005 \mathrm{a}$ & Empirical paper & American \\
\hline Malmendier and Tate & $2005 \mathrm{~b}$ & Empirical paper & American \\
\hline Lin et al. & 2005 & Empirical paper & Japan \\
\hline Wei Huang et al. & 2011 & Empirical paper & China \\
\hline Campbell et al. & 2011 & Empirical paper & American \\
\hline
\end{tabular}

Heaton's paper initiated the debate of the effect of managerial optimism on investment cash flow sensitivity. In a simple model, he theoretically demonstrates that optimism may affect the Investment decision. In other word, according to Heaton (2002) model, investment depends on the existence of cash flow and this relationship will be more pronounced by the existence of an optimistic manager. Malmendier and Tate (2005a) conduct an empirical study in the American context. They empirically demonstrate that overconfidence is an important factor that may explain investment cash flow sensitivity. Their paper is the first empirical study that explores this phenomenon under behavioral consideration. After this date, we can show that all papers in this area of research tend to include an empirical exploration in this field. A logic question is: why?

A possible explanation is that Malmendier and Tate (2005a) offer possible measures of managerial overconfidence. As we know, overconfidence and optimism seem to be very close. A thing that paves the way for others empirical papers focusing on the effect of managerial optimism in the current debate.

One advantage of the classification scheme technique is to detect some remarkable observation such as a high concentration of literature on a precise date, journal or context. Our results show that the studies are concentrated into two poles: the American framework and the Asian one. Availability of data can be justified by the use of the American context. This will be more discussed in the section relative to optimism and overconfidence measurement. While the Japanese and Chinese context are used, as is mentioned before, the publication of a special issue entitled "Behavioral Finance in Asia" by the Pacific-Bain Finance Journal. This distribution may also be simply caused by authors' affiliations. For example, Malmendier and Tate paper derivates from a chapter on doctoral thesis of Malmendier with a co-author Tate two $\mathrm{Ph}, \mathrm{D}$ student at the Harvard University in USA. As such, they may logically use the American context.

4.3. Classification of papers by the adopted approach. Despite the lack of literature in this field, the classification scheme technique is a crucial technique to understand the literature in a precise area of research. It offers a possibility to detect precise observation, anomalies and conclusions. Table 3 represents the result of classification of articles from our sample on the basis of the adopted approach.

Results highlight that all papers focusing on investment cash flow sensitivity under behavioral corporate finance adopt the irrational managers approach. This means that research in this special area of literature suppose that market are rational and so investment distortions derive from personal characteristics of the CEO, namely, they suppose that managers are affected by some psychological biases: optimism and overconfidence. But why they opt don't for the irrational investors approach?

The irrational investors approach emphasizes the effect of investor behavior that is assumed to be not fully rational. It assumes that arbitrage is imperfect and so prices can be too high or too low. Rational managers are assumed to perceive mispricing and make decisions that may encourage or respond to mispricing (Baker, 2012). This approach is silent about the 
relationship between investment and cash flow sensitivity. According to Heaton (2002), the irrational investors approach is less attractive because of the existence of the power of arbitrage in the market.

Table III: Distribution of articles by the adopted approach

\begin{tabular}{|l|l|l|}
\hline Authors & $\begin{array}{l}\text { Irrational } \\
\text { Investors } \\
\text { Approach }\end{array}$ & $\begin{array}{l}\text { Irrational } \\
\text { Managers } \\
\text { Approach }\end{array}$ \\
\hline Heaton (2002) & - & $\mathrm{x}$ \\
\hline Malmendier and Tate (2005a) & - & $\mathrm{x}$ \\
\hline Malmendier and Tate (2005b) & - & $\mathrm{x}$ \\
\hline Lin et al. (2005) & - & $\mathrm{x}$ \\
\hline Wei Huang et al. (2011) & - & $\mathrm{x}$ \\
\hline Campbell et al. (2011) & - & $\mathrm{x}$ \\
\hline
\end{tabular}

It is a reality that all research papers in this area adopt the irrational managers approach. They suppose that investors are rational and they coexist with irrational managers. CEOs are supposed to be affected by their behavioral biases and then they explore implications on corporate decisions. It is a difficult task to jointly study the interactions of irrational managers when investors are also irrational.

4.4. Classification of papers by the adopted behavioral biases. The study of behavioral finance allows cognitive psychology to play a central role in finance. Research shows that people are not fully rational and financial decision may wholly or partially be driven by behavioral biases (Kim and al, 2008). The application of behavioral finance in financial markets empirically demonstrates the effect of the behavioral biases on decision making. ${ }^{3}$

Behavioral biases are predetermining on a behavioral framework. To provide an excellent literature review of the different types of behavioral biases that financial decision maker might hold and how these biases might affect decision making and, in turn, financial markets, we can refer to Barberis and Thaler (2003). Our aim here is to identify behavioral biases that were studied in relation to investment cash flow sensitivity. Table 4 shows the detail of the classification by the adopted behavioral biases for all the reviewed articles.

Table IV: The distribution of articles by the adopted behavioral biases

\begin{tabular}{|l|l|l|l|}
\hline Authors & Optimism bias & $\begin{array}{l}\text { Overconfident } \\
\text { bias }\end{array}$ & $\begin{array}{l}\text { Other behav- } \\
\text { ioral biases }\end{array}$ \\
\hline Heaton (2002) & $\mathrm{x}$ & & - \\
\hline Malmendier and Tate (2005a) & & $\mathrm{x}$ & - \\
\hline Malmendier and Tate (2005b) & & $\mathrm{x}$ & - \\
\hline Lin et al. (2005) & $\mathrm{x}$ & & - \\
\hline Wei Huang et al. (2011) & & $\mathrm{x}$ & - \\
\hline Campbell et al. (2011) & $\mathrm{x}$ & & - \\
\hline
\end{tabular}

We show that researches in this area of finance focus on two behavioral biases: optimism and overconfident. In other words, it is assumed that managers are optimistic or overconfident. A thing that may affects the investment cash flow sensitivity. This concentration can be explained by findings in experimental psychology literature.

Research in experimental psychology documents that people in general, and especially managers, tends to be excessively optimistic and overconfident about their abilities and prospects (Oskamp, 1965; Weinstein, 1980).

\footnotetext{
${ }^{3} 3$. The beginning of this area of research was at the mid-1980s with the work of DeBondt and Thaler (1985) when they proved that stock markets overreact to information and with the work of Shefrin and Statman (1985) where they demonstrate that investors are more likely to sell their winner stocks rather than their losers.
} 
A survey by Graham and Harvey (2001) indicates that most corporate executives typically believe that their firms' equity is under valuated by the stock market. They have a rosy view of the world (Weinstein, 1980) and they are frapped by optimism bias.

Finally, we can justify the concentration of research around these two biases because simply they are well documented managerial traits (Hackbarth, 2008). We should also note that optimism and overconfidence are generally used in the same sense.

4.5. Classification of papers by the adopted measure of behavioral biases. In behavioral corporate finance the measurements of overconfidence and optimism present some difficulty as it cannot be observed directly (Campbell. et al, 2011). It is so a necessity to construct and use some practical proxies.

Malmendier and Tate (2005a) are the pioneers in constructing proxies of overconfidence in a corporate framework. They measure CEOs' overconfidence based on the CEO' net stock purchases and their stock option holding and exercising decision.

They apply three measures of overconfidence. The first measure of overconfidence compares the benchmark predictions to the actual exercise behavior of a CEO. If a CEO persistently exercises options later than suggested by the benchmark, then it will be classified as overconfident about his ability to keep the company stock price rising and wants to profit from expected stock increases by holding the options. The second measure is holding options forever. They consider that a CEO is overconfident if he ever holds an option until the last year of its duration.

According to Malmendier and Tate (2005a), there is no reason why a CEO should habitually increase his equity position by acquiring new shares or accumulating new shares or accumulating new stock grants without selling any shares to compensate. They affirm that the "habitual purchases of stock may serve as overconfidence.

They measure overconfidence on the basis of CEOs stock purchase. CEOs are classified as overconfident if they were a net buyer of company stock more years than they were a net seller during the first five years they appear in their sample.

In Malmendier and Tate (2005 b), we find another measure of managerial overconfidence. A measure based on the CEO's portrayal in the media. They collect data on how the press portrays each of the CEOs during the sample period. They search for articles referring to the CEOs in different journals: The New York Times, Business Week, Financial Times, The Economist and The Wall Street Journal. For each CEO and sample year, they record the number of articles containing the words "confident" or "confidence"; "optimistic" or "optimism"; and the number of articles containing the words "reliable", "cautious", "conservative", "practical", "frugal", or "steady". They hand-check that the terms are used to describe the CEO in question and separate out articles describing the CEO as " not confident" or " not optimistic". Finally, they construct an indicator TOTAL dummy, equal to 1 if a CEO is more often described as "confident" and "optimistic" or as "reliable", "cautious", "conservative", "practical", "frugal", or "steady".

The Malmendier and Tate measures (2005a, 2005b) of overconfidence may be classified into two categories: the first category of measures derives from the CEO actions and his portfolio selection while, the second category of measures relies on the perception of outsiders to CEOs. It means that the first category focuses on CEO's action like his behavior when holding and exercising stock options. However, this alternative approach as it initiated by Malmendier and Tate (2005b), tends to construct measures for these behavioral biases by referring to outsiders perception, namely financial journals.

Campbell et al (2011) base their measure of optimism on CEO's stock option exercising and holding decisions and on net stock purchases, and on firms' investment levels. They try also to validate their results following the media-based approach developed by Malmendier and Tate (2008). Measures based on stock option and firms shareholding are well described at the beginning of this section, we concentrate here at the fourth measure that are mentioned in previous literature on optimism and corporate investment sensitivity. 
Departing from Malmendier and Tate (2005) results and from theoretical implications of their developed model, Campbell et al (2011) suggest that firm investment may contain information about CEO optimism. They classify CEOs as having low (high) optimism if their firm is in the bottom (top) quintile of firms sorted on industry-adjusted investment rate for two consecutive years. They justify the imposition of two year requirement because investment is lumpy through time, and they do not want to identify firms that just happen to bunch investment in one year.

Huang et al. (2011) propose to measure over confidence in the Chinese context. In view of the data availability and financial conditions for China's stock exchange-listed company, they construct two proxies for top executives' overconfidence. The first proxy is the difference between top executives forecasted earning and actual earning. They use a simple criterion to classify top executives as overconfident only if the number of times of over-forecast is more than that of under-forecast during the entire sample forecast. They define over-forecast as the case where forecasted earnings are greater than actual earnings, while under-forecast as the case where forecasted earning are smaller than actual earnings. In their papers the "confidence" variable is a static measure that has one observation per top executives or firm. This measure of overconfidence is developed around Lin et al. (2005) approach and many other works such as Li and Tang (2010) and Hribar and Yang (2010), who also provide the robustness of this measure in a non-static situation.

The second measure consists in the use of top executives' relative salary as proxy for managerial overconfidence. Theoretical background of this measure refers to Hayward and Hambirk (1997) who argue that a high salary of manager may introduce him to be overconfident. Research by Brown and Sarma (2006), show that higher CEO's relative salary is associated with stronger dominance of power. Moreover, it is demonstrated that more powerful CEOs are more likely overconfident (Sivanathan and Galinsky (2007). The salary information for top three managers is used in order to measure overconfidence. The final measure of top executives' overconfidence is the sum of top three managers' salaries to the sum of all managers' salaries and the greater this ratio is, the higher top executives overconfidence will be. We note that this last measure is similar to Frith et al. (2006, 2007)'s measure.

Lin et al. (2005) propose a managerial optimism measure on CEOs personal estimation of firms earning. Departing from managerial earnings forecasts, and accepting that all forecasts are equally weighted, they classified CEOs as optimistic managers or not. They classify whether a CEO as optimistic if he/she has at least two forecasts, and define a CEO to be optimistic if there are more upwardly-biased forecasts than downwardly-biased forecasts during the CEO's tenure. They defined a forecast as upward biased if the forecast error is positive. This error is simply defined as the difference between managers' earnings forecasts and the actual earnings before tax.

In sum, we identify five measures of managerial optimism or overconfidence. Measure 1 indicates the use of stock holding and exerting behavior, measure 2 indicates the use of Net Buyer measure, measure 3 indicates the use of a measure based on press portrays of CEOs during the sample period, measure 4 is relative to the use of the earning forecast error and finally, measure 5 concerns the use of top-managers salaries to construct proxy for managerial overconfidence. We ignore some additional measures such as firm investment level because they cannot be applied to test investment cash flow sensitivity.

Table V: Distribution of articles by the adopted measures of behavioral biases

\begin{tabular}{|l|l|l|l|l|l|}
\hline Authors & Measure 1 & Measure 2 & Measure 3 & Measure 4 & Measure 5 \\
\hline Heaton (2002) & & & & & \\
\hline Malmendier and Tate (2005a) & $\mathrm{x}$ & $\mathrm{x}$ & & & \\
\hline Malmendier and Tate (2005b) & & & & $\mathrm{x}$ & $\mathrm{x}$ \\
\hline Lin et al. (2005) & & $\mathrm{x}$ & & $\mathrm{x}$ & \\
\hline Wei Huang et al. (2011) & & & $\mathrm{x}$ & & \\
\hline Campbell et al. (2011) & $\mathrm{x}$ & $\mathrm{x}$ & & & \\
\hline
\end{tabular}


The largest use of Net Stock holding can be explained mainly by two things. The first reason is the availability of information that we need in comparing the stock options holding and exercising information. The second one is the fact that this measure is useful to apply. Departing from insiders trading, we determinate the net position in firms' stock and so we can simply generate proxy from managerial optimism by computing the number where the CEO is a net Bayer and those where not (Malmendier and Tate 2005) or we can use the net position of the CEO in his stock firm as is prescribed by Campbell et al (2011).

An interesting remark here is that the optimism measure developed by Campbell and al. (2011) in the basis of the Malmendier and Tate (2005) work is advantageous because it generates a dynamic measure of managerial optimism year by year. The challenge is if this new measure is proper to test investment cash flow hypothesis, proxy of managerial optimism here may be the result of asymmetric information: manager who knows exactly the financial situation of his firm and future opportunity of growth will probably act according to this private information. In this case, sales or acquisitions of shares are just related to a rational reaction and it is far from the optimism or overconfidence impact.

In sum, we can classify the adopted measure of managerial overconfidence and optimism into three categories. The first one is on the basis of CEOs actions such as options holding and exercising, firm's shares purchases, and managerial forecasts. The second category is based on outsiders' perceptions, namely the media and the financial journals perception. The final category includes other measures that are related to firm investment level and the top three managers' salaries. Table 5 classifies measures used in papers from our sample into these three categories.

Table VI: Classification of optimism and overconfidence measures into three categories

\begin{tabular}{|l|l|l|l|}
\hline Authors & $\begin{array}{l}\text { Measures of } \\
\text { CEOs based } \\
\text { actions }\end{array}$ & $\begin{array}{l}\text { Measures } \\
\text { based on } \\
\text { media per- } \\
\text { ceptions }\end{array}$ & $\begin{array}{l}\text { Measures } \\
\text { based on } \\
\text { firms in- } \\
\text { vestment } \\
\text { level and } \\
\text { salaries }\end{array}$ \\
\hline Heaton (2002) & & & \\
\hline Malmendier and Tate (2005a) & $\mathrm{x}$ & & \\
\hline Malmendier and Tate (2005b) & $\mathrm{x}$ & & \\
\hline Lin et al. (2005) & $\mathrm{x}$ & & \\
\hline Wei Huang et al. (2011) & & $\mathrm{x}$ & \\
\hline Campbell et al. (2011) & $\mathrm{x}$ & & $\mathrm{x}$ \\
\hline
\end{tabular}

The classification of optimism and overconfidence measures shows that most of the research papers adopt measures based on CEO's actions. They link the measures of behavioral biases into the proper actions of managers. The large use of these measures may be justified by its superiority to other categories of measures.

Authors may be constrained by data availability when choosing between optimism and overconfidence measures. Measures based on stock options exercising and holding depend on the context of the study. For example, data concerning the stock options are very limited out of the United States. Other measures are also seemed to be unrealizable because of the large observations in data bases. This is the case when Campbell and al., (2011) want to adopt measures based on media portray. They affirm that "Our sample construction begins with the ExecuComp population and contains over 12,000 CEO-year observations. Given the sample size, it is infeasible to hand collect measures based on media's perception of the CEO's level of optimism".

Another remarkable thing is that research in behavioral corporate finance uses, at the most of cases, more than one optimism or overconfidence measures the same study. This maybe 
is not a choice but an obligation under the difficulties to measure behavioral biases that are unobservable directly. The use of a panoply of measures aims to guarantee the robustness of optimism and overconfidence measures and then robustness and validity of results.

Finally, measures' validities are always protected by two hypotheses: the absence of agency conflicts and the absence of asymmetric information. These assumptions have another objective; they absorb all potential explanation of investment cash flow sensitivity that can be generated by these two theories.

Some works study the effect of managerial overconfidence in the presence of agency problems, but they support the absence of asymmetric information's assumption. The persistence of the second assumption highlights explanatory power and its role in measures validity and results robustness. If we accept the presence of information's asymmetry, then measures based on CEOs the actions may be perceived as signaling strategy. According to Ross (1977) model, manager may purchase his own firm's shares in order to pass a positive signal to the financial markets on the quality of his management and on the good health of his firm. As is mentioned before, the use of measures such as the net shares purchasing when controlling for the existence of managerial behavioral biases will affect dramatically the robustness of results in the presence of information asymmetry problem.

We discuss the adopted assumptions in each considered work in the next classification. Remarks and discussion will be offered in order to understand the details of each work. This will be possible if we take into consideration the lack of articles in this field of literature, which makes it possible to discuss in detail each paper.

4.6. Classification of papers by the adopted assumptions. Behavioral corporate finance aims to explain corporate investment distortions (overinvestment, underinvestment and investment cash flow sensitivities) mainly by personal characteristics of managers. Such distortions were largely explained in the standard finance by agency conflicts and information's asymmetry.

When discussing investment cash flow sensitivity, previous traditional literature researches evoke three important explanations of investment distortions. The first one concerns the effect of agency theory. Conflicts of interests in the firm may be a possible source of the deviation of investment from the norms and may cause investment cash flow sensitivity. The second one links investment distortions, including the investment cash flow sensitivity, to asymmetric information's theory. Another important explanation is discussed by Fazzari et al., (1988) and Kaplan and Zingales $(1997,2000)$ which explore the effect of financial constraints on investment cash flow sensitivity.

Table VII: Distribution of articles by the adopted assumptions

\begin{tabular}{|l|l|l|l|}
\hline Authors & $\begin{array}{l}\text { Absence of } \\
\text { agency' con- } \\
\text { flicts }\end{array}$ & $\begin{array}{l}\text { Absence of } \\
\text { asymmetric } \\
\text { information }\end{array}$ & $\begin{array}{l}\text { The ex- } \\
\text { istence } \\
\text { of firms' } \\
\text { financial } \\
\text { constraint }\end{array}$ \\
\hline Heaton (2002) & $\mathrm{x}$ & $\mathrm{x}$ & \\
\hline Malmendier and Tate (2005a) & $\mathrm{x}$ & $\mathrm{x}$ & $\mathrm{x}$ \\
\hline Malmendier and Tate (2005b) & $\mathrm{x}$ & $\mathrm{x}$ & $\mathrm{x}$ \\
\hline Lin et al. (2005) & $\mathrm{x}$ & $\mathrm{x}$ & \\
\hline Wei Huang et al. (2011) & & $\mathrm{x}$ & \\
\hline Campbell et al. (2011) & $\mathrm{x}$ & $\mathrm{x}$ & \\
\hline
\end{tabular}

Heaton (2002) affirms that "To explore managerial optimism's explanatory power, it is important to isolate its effects from the influence of assumptions made by the two predominant approaches to corporate finance: the asymmetric information approach and the empirebuilding/rational agency cost approach"

Beyond the standard finance's explanations and to neutralize the effect of these potential justifications of investment cash flow sensitivity, behavioral corporate finance supposes generally 
the absence of agency problems and asymmetric information. As is discussed above, the first and the second assumptions aim to neutralize potential explanations that can derive from them. Another justification is that these assumptions are powerful factors and may affect optimism and overconfidence measures.

Huang et al., (2011) works' is the first one that empirically investigates the effect of managerial overconfidence on investment with the presence of agency costs. The main measure of overconfidence in their paper is the net purchasing firms' shares. The validity of this measure is more related to the absence of asymmetric information than to the absence of agency conflicts.

Malmendier and Tate (2005a, 2005b) explore investment cash flow sensitivity under managerial overconfidence with the absence of agency costs and information asymmetry but they reintroduce the firms' financial constraints as factors that may still have an explanatory power on this new behavioral framework.

Finally, we highlight that there are some other assumptions but they are less developed in empirical studies. Heaton (2002), in his theoretical paper, suppose that capital market is rational and markets are efficient. This assumption should be relaxed in order to study the interactions between irrational managers and inefficient markets.

4.7. The classification of papers by empirical findings. Investment cash flow sensitivity is simply the study of the sensitivity of firms' corporate investment to the availability of internal cash flow. Finance literature focuses on what may derive this relationship?

Standard finance literature empirically proves the existence of investment cash flow sensitivity and it demonstrates that this sensitivity depends mainly on the existence of agency costs and asymmetric information. According to Fazzari et al., (1988) and Kaplan and Zingales (1997, 2000), firms' financial constraints may amplify the intensity of this sensitivity.

From a behavioral corporate finance point of view, the psychological biases are at the heart of the debate and so, their introduction as potential explanations of corporate investment distortions may answer the open question: "Corporate investment cash flow sensitivity: who derives this relationship?". Table 8 summarizes findings of the effect of managerial optimism and overconfidence on investment cash flow sensitivity.

Table VIII: Distribution of articles by theoretical and empirical findings

\begin{tabular}{|l|l|l|}
\hline Authors & Nature of papers & Empirical findings \\
\hline Heaton (2002) & theoretical & + \\
\hline Malmendier and Tate (2005a) & empirical & + \\
\hline Malmendier and Tate (2005b) & empirical & + \\
\hline Lin et al. (2005) & empirical & + \\
\hline Wei Huang et al. (2011) & empirical & + \\
\hline Campbell et al. (2011) & empirical & + \\
\hline
\end{tabular}

Heaton (2002) theoretically predicts an investment cash flow sensitivity phenomenon caused by managerial optimism. Optimistic CEOs will reject project that do not have sufficient cash flow to finance them internally (or cannot issue risk-free debt). This will induce a positive correlation between cash flow and investment.

Malmendier and Tate (2005a) test the overconfidence hypothesis and find that investment of overconfident CEOs is significantly more responsive to cash flow. Applying a revisited measure of managerial overconfidence based on outsiders perception of the CEOs (CEOs 'press portrayals) reinvestigation of the relationship between corporate investment and cash flow corroborates the Malmendier and Tate (2005a) 'findings. Huang et al. (2011) conclude that investment cash flow sensitivity is more pronounced with overconfidence executives and persists in the Chinese context.

Lin et al. (2005) conduct an empirical study to explore the extent to which managerial optimism provides a satisfactory explanation for the investment decision of the listed Taiwanese firms. They focus on whether cash flow plays a relatively more important role in investment decision for optimistic managers than for non-optimistic ones. They evoke the possibility that 
firms' may be financially constrained. An investment cash flow sensitivity phenomenon persists in the Taiwanese context; optimistic managers exhibit higher investment-cash flow sensitivity than do non-optimistic managers. Campbell et al. (2011) validate this empirical finding in the American context.

It is seems that behavioral corporate finance succeeds to theoretically predict a potential explanation of corporate investment distortions. Empirical studies focusing on the effect of managerial overconfidence and optimism on investment cash flow sensitivity prove the existence of a positive correlation between investment and cash flow. Corporate investment will be more sensitive to internal cash flow in the case of optimistic or overconfident managers than with non-optimistic or non-overconfident managers. The psychological biases are one for them who derives the investment cash flow sensitivity relationship.

4.8. Classification of papers by the adopted econometric approach. Investment cash flow sensitivity is studied using only the Q-investment model. We exclude the Heaton (2002) paper which has a theoretical nature. It is true that the Q-model is advantageous because it uses information from the capital market so it can generate direct measure of expected value of firm's future profitability. It is also more informative (George et al. 2011), but what happened if the stock markets prices are inefficient? In this case, the use of Q can be an imprecise proxy for the value of additional unit of capital.

Empirical results on investment cash flow sensitivity may be the result of econometric bias deriving from limits of the Q-model. The Euler equation model can be an alternative approach since it is based on the exploration of the relationship between corporate investments in successive time periods and so it has the advantage of not requiring explicit use of future values (Bond and Meghir, 1994).

Table IX: Distribution of articles by the adopted econometric approach

\begin{tabular}{|l|l|l|}
\hline Authors & Q-investment model & Euler equation model \\
\hline Heaton (2002) & $\mathrm{x}$ & - \\
\hline Malmendier and Tate (2005a) & $\mathrm{x}$ & - \\
\hline Malmendier and Tate (2005b) & $\mathrm{x}$ & - \\
\hline Lin et al. (2005) & $\mathrm{x}$ & - \\
\hline Wei Huang et al. (2011) & $\mathrm{x}$ & - \\
\hline Campbell et al. (2011) & $\mathrm{x}$ & - \\
\hline
\end{tabular}

Researches testing the investment cash flow sensitivity under managerial optimism using these two simultaneous models of investment are absent until now, a thing that can affect the quality of empirical results in this field of research.

\section{BCF: FROM THE STUDY OF INVESTMENT CASH FLOW SENSITIVITY TO THE DISCUSSION} OF FIRMS' INVESTMENT EFFICIENCY

After this comprehensive literature review, we show that behavioral corporate finance has focused on investment cash flow sensitivity and it validates the effect of managerial optimism on corporate investment policy. In general, empirical studies report that managerial optimism increases investment cash flow sensitivity and this will be greater when firms run financial constraints. Huang et al., (2011) enlarge the debate when they propose to jointly analyse the effect of managerial optimism in the presence of agency costs in the Chinese context.

A major critic of this work is that they concentrate on the discussion of a common problematic with minor innovations. There is a tendency to contextualize the original study of Malmendier and Tate (2005a), a fact that can explain the small body of literature in this field. Behavioral corporate finance should open new debate and investigate the effect of managerial optimism in a corporate investment by discussing other related subjects such as the effect of managerial optimism on firm value and the corporate investment efficiency.

The study of the effect of managerial optimism on corporate investment constitutes one of the most interesting potential subjects of research. Motivations of such new area of research 
come from empirical findings on the effect of managerial optimism on corporate investment and cash flow relationship. Optimism seems to have a powerful explanatory power on explaining corporate investment distortions. So, we should interrogate about the existence of a significant relationship between firms' investment and the optimism level of their CEOs. Can managerial optimism really explain investment inefficiency?

It is also possible to discuss the efficiency of firms' observed Tobin's $\mathrm{Q}$ and the optimal Tobin's Q*. In a seminal paper, Habib et al., (2005) and Pawlina and Renneboog (2005) offer an excellent framework to initiate such debate in a behavioral framework. It is possible to model the efficiency of firms' investment or growth opportunities and to explain the observed inefficiency by CEOs optimism and other traditional variables, especially those related to agency costs and asymmetric information problems. To sum up, we discuss some other potential future directions' of research.

\section{Conclusion and future Research Directions}

This paper is an essay to survey literature in investment cash flow sensitivity under behavioral corporate finance. To our knowledge, there are few survey papers focusing on behavioral corporate finance and no paper that has the same subject of this paper.

This research has surveyed the existent articles on this area of finance. In contrast to the research into behavioral finance, the research into behavioral corporate finance is still relatively young (Fairchild, 2007). So, only 6 articles were surveyed. In fact, we conduct an electronic search of published work on this field among scientific journals between 2002 and June 2011. Only these 6 articles are found.

A classification scheme technique was developed in order to make a comprehensive literature review. Readers should be cautious in interpreting the results of this literature survey, since the findings are based on data collected only from academic journal articles. We assume that highquality research is eventually published in academic journals. The literature search procedure may also cause some limitations because it is based on papers title, key words or abstracts. It is true that the title in most cases describes the content quite well. This is not always the case.

Notwithstanding these limitations, it is believed that this study provides some reasonable insights and future directions into investment cash flow sensitivity under behavioral corporate finance. Based on the review, classification and analysis of the articles, some broad suggestions for future research can be advanced:

1) First, the classification by articles of context highlight that research in this field are restraint into only two contexts: the American context and the Asiatic one (Japan and China). Behavioral corporate finance should depart from these contexts to study investment cash flow sensitivity in European or African contexts. This is in order to generalize theoretical predictions and empirical findings and to neutralize the context's effect on the relationship between corporate investment and internal cash flow sensitivity. It is primordial to assure that sensitivity is independent from the context of the study.

2) The classification scheme technique shows a concentration of studies on the effect of only two behavioral biases: optimism bias and overconfidence. A potential growth of literature may be possible with the adoption of other psychological biases. We show also that optimism and overconfidence biases are studied as if they are a simply one bias. They have the same effect and they may also have the same measures. It is time to distinguish between them. Optimism should be studied as an overestimation of the means while overconfidence should be evaluated as an underestimation of the variance.

3) Measures of optimism and overconfidence are close to assumptions that may not always be realistic. It is assumed in most of cases that agency costs and asymmetric information are absent. There are at least two possible explanations: behavioral corporate finance aims to prove the effect of managers' psychological characteristics on corporate decisions. This is why it trays to neutralize potential explanations from these theories. Another possible explanation is that validity measures are depending on these assumptions. 
4) An interesting approach may arise if we find some measures of optimism and overconfidence that are robust, even the existence of agency costs and asymmetric information. This new approach is very attractive since it will offer the possibility to explore the influence of these biases and to see their interactions with the effect of agency and asymmetric information theories.

5) The emergence of a new framework where irrational managers existing with irrational investors should be developed. Behavioral corporate finance should investigate the interactions of irrational behaviors from these two poles. Implications on investment cash flow sensitivity should be discussed.

6) Another interesting point is to study the effect of optimism and overconfidence not only on the CEO. In fact, he/she is not alone responsible for the efficiency of corporate investment decisions. Researchers are invited to generalize their studies in order to include other insiders such as chief financial officer and other members of the board of directors. Translation of the study of personal characteristics from top management to optimism or over confidence seems to offer a more realistic framework to detect the effect of psychological biases on firms 'decisions.

7) Investment cash flow sensitivity is still unexplored for the research and development activities. It is still an open question in the financial literature: is the impact of managerial optimism on research and development investment similar to that on fixed assets investment? This is a central question in the Q literature under behavioral corporate finance. Can the characteristics of research and development investment, especially the specificity of such investment (as is inspired by the transaction costs theory) influence the effect of managerial optimism on firm's investment? This question should be resolved and it will be used as a reply to the attractive question of Hirshleifer et al., (2012) in a forthcoming paper that will be published by the journal finance: "Are Overconfident CEOs Better Innovators?" They empirically demonstrate that optimistic CEOs invest more in innovation and that optimism may help CEOs explore innovative growth opportunities. However, it is crucial to study research and development cash flow sensitivity to ensure if they still prefer internal cash flow to finance their innovation projects. Then, their cited conclusions should be revised to include the impact of optimism on innovation's investment with evoking the firm's financial constraint. Overconfident CEOs may be better innovator but in less constrained firms.

8) Behavioral corporate finance focuses on how psychological biases affect managers' decision and so how they may explain corporate investment distortions. Future directions of research could discuss the manner of which firms will succeed to neutralize possible distortions in corporate investment deriving from optimism, overconfidence and other psychological biases.

9) Investment cash flow sensitivity under managerial optimism was studied using the Qmodel of investment, a fact that can reduce the significance of results. The positive coefficient between investment and cash flow multiplied by managerial optimism may be the result of econometric bias that is due to limitations of Q-model.

Acknowledgement. We thank Pr. Richard Fairchild from the School of Management, University of Bath UK for his continuous helps and critics during the development of this paper. We also thank the Editor in Chief of RFB and two anonymous reviewers for their comments.

\section{REFERENCES}

[1] Ãgca, S., \& Mozumdar, A. (2008). The impact of capital market imperfections on investment-cashflow sensitivity. Journal of Banking and Finance, 32, 207-216.

[2] Aggarwal, R., \& Zong, S. (2006). The cash flow-investment relationship: international evidence of limited access to external finance. Journal of Multinational Financial Management, 16, 89-104.

[3] Allayannis, G., \& A. Mozumdar, (2004). The impact of negative cash flow and influential observations on investment-cash flow sensitivity estimates. Journal of Banking and Finance, 28, 901-930.

[4] Hovakimian, A., \& Hovakimian, G. (2009). Cash flow sensitivity of investment. European Financial Management, 15(1), 47-65. 
[5] Baker, M., Ruback, R,. \& Wurgler, J. (2012). Behavioral corporate finance: an updated survey. in E. Eckbo (Ed.), The Handbook of Corporate Finance: Empirical Corporate Finance (pp.145-188). New York : North Holland.

[6] Barberis, N., \& Thaler, R. (2003). A survey of behavioral finance. In G. Constantinides, M. Harris, \& R. Stulz (Eds.), Handbook of the economics of finance: Volume 1B, Financial markets and asset pricing (1st ed.) (pp. 1053-1128). Amsterdam : Elsevier North-Holland.

[7] Boehmer, E., \& Netter, J. (1997). Management optimism and corporate acquisitions: Evidence from insider trading. Managerial and Decision and Economics, 18, 693-708.

[8] Bond, S., \& Meghir, C. (1994). Dynamic investment models and the firm's financial policy. Review of Economic Studies, 61, 197-222.

[9] Brown, R., \& Sarma, N. (2007). CEO overconfidence, CEO dominance and corporate acquisations. Journal of Economics and Business, 59, 358-379.

[10] Campbell, T., Gallmeyer, M., Jhonson, S., Rutherford, J., \& Stanley, B. (2011). CEO optimism and forced turnover. Journal of Financial Economics, 101(3), 695-712.

[11] Cavusgil, S. T. (1995). A classification and assessment of research streams in international marketing. International Business Review, 4(3), 251-277.

[12] Degryse, H., \& de Jong, A. (2000). Investment spending in the Netherlands: The impact of liquidity and corporate governance. CentER Discussion Paper No. 2000-24, Tilburg University.

[13] Fairchild, R. (2007). Managerial overconfidence, agency problems, financing decision and firm performance. Working Paper Series 2007.11, School of Management, University of Bath, Bath, UK.

[14] Fazzari, S., Hubbard, R. G. \& Bruce, P. (1998). Financing constraints and corporate investment. Brookings Paper on Economic Activity Vol.1 (pp.141-195).

[15] Firth, M., Fung, P.M.Y., \& Rui, O.M. (2006). Corporate performance and CEO compensation in China. Journal of Corporate Finance, 12, 693-714.

[16] Firth, M., Fung, P.M.Y., \& Rui, O.M., (2007). How ownership and corporate governance influence chief executive pay in China's listed firms. Journal of Business Research, 60(7), 776-785.

[17] George, R., Rezaul, K., \& Jing, Q. (2011). Investment-cash flow sensitivity and financing constraints: New evidence from Indian business group firms. Journal of Multinational Financial Management, 21(2), 69-88.

[18] Goergen, M., \& Renneboog, L. (2001). Investment policy, internal financing and ownership concentration in the UK. Journal of Corporate Finance, 7, 257-284.

[19] Graham, J. R. \& Harvey, C. R. (2001). Theory and practice of corporate finance: Evidence from the field. Journal of Financial Economics, 60, 187-243.

[20] Gugler, K., \& Yurtoglu, B. B. (2003). Average Q, Marginal Q, and the Relation between Ownership and Performance. Economics Letters, 78, 379-384.

[21] Gugler, K. (2003). Corporate governance and investment. International Journal of the Economics of Business, 10, 261-289.

[22] Habib, M. A., \& Ljungqvist, A. P. (2005). Firm value and managerial incentives. Journal of Business, 78(6), 2053-2094

[23] Hackbarth, D. (2008). Managerial traits and capital structure decisions. Journal of Financial and Qualitative Analysis, 43(4), 843-882.

[24] Hackbarth, D. (2009). Determinants of corporate borrowing: A behavioural perspective. Journal of Corporate Finance, 15, 389-411.

[25] Hadlock, C. J. (1998). Ownership, liquidity and investment. RAND Journal of Economics, 29, 487-508.

[26] Haid, A., \& Weigand, J. (2001). R\&D investment, liquidity constraints, and corporate governance. Jahrbücher für Nationalökonomie und Statistik, 221, 145-167.

[27] Harris, M. \& Raviv, A. (1991).The theory of capital structure. Journal of Finance, 46(1), 299-355.

[28] Hayward, M.L.A., \& Hambrick, D.C. (1997). Explaining the premiums paid for large acquisitions: Evidence of CEO hubris. Administrative Science Quarterly, 42, 103-127.

[29] Heaton, J.B. (2002). Managerial optimism and corporate finance. Financial Management, 31(2), 33-45.

[30] Hirshleifer, D. A., Teoh, S. H. \& Low, A. (2012). Are overcondent CEOs better innovators? Journal of Finance, 67(4), 1457-1498.

[31] Hribar, P., \& Yang, H. (2010). Does CEO overconfidence affect management forecasting and subsequent earnings management? SSRN Working Paper.

[32] Huang, W., Jiang, F., Liu, Z., \& Zhang, M. (2011). Agency cost, top executives' overconfidence, and investment-cash flow sensitivity: Evidence from listed companies in China. Pacific-Basin Finance Journal, $19,261-277$.

[33] Hubbard, R. (1998). Capital-market imperfections and investment. Journal of Economic Literature, 36, $193-225$.

[34] Jensen, M. (1986). Agency costs of free cash flow, corporate finance and takeovers. American Economic Review, 76, 323-329.

[35] Jensen, M.C., \& Meckling, W.H. (1976). Theory of the firm: managerial behavior, agency costs and ownership structure. Journal of Financial Economics, 3, 305-360. 
[36] Kahneman, D \& Tversky, A. (1979). Prospect theory: An analysis of decision under risk. Econometrica, 47, 263-291.

[37] Kaplan, S. N. \& Zingales, L. (1997). Do investment cash flow sensitivities provide useful measure of financing constraints? Quarterly Journal of Economics,112, 169-215.

[38] Kathuria, R. \& Mueller, D.C. (1995) Investment and cash flow: Asymmetric information or managerial discretion. Empirica, 22, 211-234

[39] Kim, K., R. \& Nofsinger, J. (2008). Behavioral finance in Asia. Pasific-Basin Finance Journal, 16, 1-7.

[40] Kluemper, D., Little, L., \& DeGroot, T. (2009). State or trait: effects of state optimism on job-related outcomes. Journal of Orgnizational Behavior, 30, 209-231.

[41] Laeven, L. (2003). Does financial liberalization reduce financing constraints? Financial Management, 32, $5-34$.

[42] Lin, Y., Hu, S., \& Chen, M. (2005). Managerial optimism and corporate investment: Some empirical evidence from Taiwan. Pacific-Basin Finance Journal, 13, 523- 546.

[43] Lin, Y., Hu, S., \& Chen, M. (2008). Testing pecking order prediction from the viewpoint of managerial optimism: some empirical evidence from Taiwan. Pacific- Basin Finance Journal, 16, 160-181.

[44] Lopes, L. L. (1987). Between hope and fear: The psychology of risk. Advances in Experimental Social Psychology, 20, 255-295.

[45] Malmendier, U., \& Tate, G., Yan, J. (2007). Corporate financial policies with overconfident managers. NBER Working Paper No. 13570.

[46] Malmendier, U., \& Tate G. (2008). Who makes acquisitions? CEO overconfidence and the market's reaction. Journal of Financial Economics, 89, 20-43.

[47] Malmendier, U., \& Tate, G. (2005b). Does overconfidence affect corporate investment? CEO overconfidence measures revisited. European Financial Management, 11(5), 649-59.

[48] Malmendier, U., \& Tate, G. (2005a). CEO overconfidence corporate investment. Journal of Finance, LX(6), $2661-2770$

[49] Marasco, A. 2008. Third-party logistics: A literature review. International Journal of Production Economics $113,127-147$.

[50] Modigliani, F., and Miller, M. H. (1958). The cost of capital, corporate finance and the theory of investment. American Economic Review, 48, 261-97.

[51] Myers, S.C., \& Majluf, N.S. (1984). Corporate financing and investment decisions when firms have information that investors do not have. Journal of Financial Economics, 13, 187-221.

[52] Oskamp, S. (1965). Overconfidence in case-study judgments. The Journal of Consulting Psychology, 29, 261-265.

[53] Pallier, G., Wilkinson, R., Danthiir, V., Kleitman, S., Knezevic, G., Stankov, L. \& Roberts, R. D. (2002). The role of individual differences in the accuracy of confidence judgements. The Journal of General Psychology, 129(3), 257-299.

[54] Pawlina, G., \& Renneboog, L. (2005). Is investment-cash flow sensitivtity caused by the agency costs or asymmetric information? Evidence from the UK. European Financial Management, 11(4), 483-513.

[55] Pindado, J., \& de la Torre, C. (2004). The effect of ownership structure on underinvestment and overinvestment processes. EFMA 2004 Basel Meetings Paper.

[56] Ross, S.A. (1977). The determinants of financial structure: the incentive signalling approach. The Bell Journal of Economics, 8, 23-40

[57] Seuring, S., Muller, M., Westhaus, M., \& Morana, R. (2005). Conducting a literature review: The example of sustainability in supply chains. In H. Kotzab, S. Seuring, M. Muller, \& G. Reiner (Eds.), Research Methodologies in Supply Chain Management (pp. 91-106). Heidelberg : Physica.

[58] Shefrin, H. (2005). Behavioral corporate finance. Journal of Applied Corporate Finance, 14(3), 113-126.

[59] Shefrin, H., \& Statman, M. (2000). Behavioral portfolio theory. Journal of Financial and Quantitative Analyses, 35, 127-151.

[60] Shen, C. H., \& Wang, C. A. (2005). Does bank relationship matter for a firm's investment and financial constraints? The case of Taiwan. Pacific-Basin Finance Journal, 13, 163-184.

[61] Shi, Y. (2009). Three essays on the dark side of managerial compensation. Doctoral dissertation, The University of Texas at San Antonio, Proquest publisher, UMI No. 3368807.

[62] Sivanathan, N., \& Galinsky, A.D. (2007). Power and overconfidence.Paper presented at the meetings of the International Association of Conflict Management: Budapest, Hungary.

[63] Statman, M. ( 2005). Normal investors, then and now. Financial Analysts Journal, 61(2), 31-36.

[64] Weinstein, N. D. (1980). Unrealistic optimism about future life events. Journal of Personality and Social Psychology, 39, 806-820.

[65] Zingales, L. (2000). In search of new foundations. Journal of Finance, 55(4), 1623-1653. 